University of Nebraska - Lincoln

DigitalCommons@University of Nebraska - Lincoln

Agronomy \& Horticulture -- Faculty Publications

Agronomy and Horticulture Department

$1-1986$

\title{
Registration of NP25 Low-dhurrin Sudangrass Germplasm
}

Francis A. Haskins

University of Nebraska-Lincoln, fhaskins@neb.rr.com

Herman J. Gorz

United States Department of Agriculture

S. D. Kindler

United States Department of Agriculture

S. G. Jensen

United States Department of Agriculture

A. Sotomayor-Rios

United States Department of Agriculture

Follow this and additional works at: https://digitalcommons.unl.edu/agronomyfacpub

Part of the Plant Sciences Commons

Haskins, Francis A.; Gorz, Herman J.; Kindler, S. D.; Jensen, S. G.; and Sotomayor-Rios, A., "Registration of NP25 Low-dhurrin Sudangrass Germplasm" (1986). Agronomy \& Horticulture -- Faculty Publications. 252. https://digitalcommons.unl.edu/agronomyfacpub/252

This Article is brought to you for free and open access by the Agronomy and Horticulture Department at DigitalCommons@University of Nebraska - Lincoln. It has been accepted for inclusion in Agronomy \& Horticulture -Faculty Publications by an authorized administrator of DigitalCommons@University of Nebraska - Lincoln. 
families were assayed for dhurrin content, and equal volumes of remnant seed from the lowest $25 \%$ of the $S_{1}$ families were composited and planted in isolation for a second random mating. Seed for distribution was harvested separately from male-sterile and fertile plants.

The spectrophotometric assay (1) for hydrocyanic acid potential of first leaves from 1-week-old seedlings grown in the same test resulted in the following values for means and standard errors ( $\mathrm{mg} \mathrm{kg}^{-1}$ fresh weight, bulk of 10 seedlings per replication, five replications): NP25 fertile bulk$183 \pm 8$; NP25 male-sterile bulk-164 $\pm 10 ;$ NP22-308 \pm 17 ; NP23-399 \pm 21; NP24-744 \pm 19 ; Piper-381 \pm 36 ; and 'Greenleaf' $-532 \pm 40$.

The seed being released as NP25 has not been grown in a yield trial, but a 1 -yr replicated test at Mead, NE in 1982 , using seed bulked from the $128 \mathrm{~F}_{6}$ plants random-mated in 1981, suggests that the seasonal dry matter yield of NP25 may be substantially lower than for Piper or Greenleaf. However, in the same test, yield differences among Piper, Greenleaf, a hybrid of 'A Redlan' $\times$ Greenleaf, and a hybrid of ARedlan $X$ the $F_{4}$ plants from which NP25 was derived were not statistically significant.

It appears, therefore, that NP25 may have potential for use in sorghum-sudangrass hybrids and possibly in true sudangrass hybrids, but its use for forage as a cultivar does not appear to be promising. However, NP25 should serve as an excellent source of low dhurrin content in sudangrass breeding programs.

Germplasm amounts of two different types of NP25 seed are available for distribution: 1) bulked seed harvested from male-sterile plants, 2) bulked seed harvested from fertile plants. Requests should be submitted to the Department of Agronomy, University of Nebraska, Lincoln, NE 68583.

F. A. Haskins, H. J. Gorz, S. D. Kindler, S. G. Jensen, AND A. SOTOMAYOR-RIOS (2)

\section{References and Notes}

1. Gorz, H.J., W.L. Haag, J.E. Specht, and F.A. Haskins, 1977. Assay of $p$-hydroxybenzaldehyde as a measure of hydrocyanic acid potential in sorghums. Crop Sci. 17:578-582.

2. George Holmes professor of agronomy, Univ. of Nebraska, Lincoln, NE supervisory research geneticist, USDA-ARS, Lincoin, NE; research entomologist, USDA-ARS, Lincoln, NE; research plant pathologist, USDA-ARS, Lincoln, NE; and supervisory research agronomist, USDA-ARS, Mayaguez, PR 00709, respectively. Cooperative investigations of USDA-ARS and the Nebraska Agric. Res. Div. Published as Paper no. 7726, Journal Series, Nebraska Agric. Res. Div. Registration by the Crop Sci. Soc. of Am. Ac-

NP25 sudangrass [Sorghum bicolor (L.) Moench] (Reg. no. GP-180), a low-dhurrin, random-mating population that carries the $m s_{3}$ gene for genetic male sterility, was developed cooperatively by USDA-ARS and the Nebraska Agricultural Research Division and released in April 1984 Plants of NP25 are leafy and fine-stemmed, 160 to $170 \mathrm{~cm}$ in height with dry stalks (white midrib), tan plant color, sienna glumes, and brown pericarp. NP25 restores fertility to hybrids when crossed to male steriles with Al cytoplasm.

The synthesis of NP25 was accomplished by crossing malesterile ( $m s_{\mathbf{3}} m s_{\mathbf{3}}$ ) sudangrass segregates in two successive generations with two different selections of sudangrass germplasm derived from commercial sources, followed by a similar cross in the third generation with a low-dhurrin selection from the sudangrass cultivar Piper. Following the third cross, $F_{1}$ plants were self-pollinated, and seedlings from the $\mathrm{F}_{2}$ and succeeding generations were assayed for dhurrin content (1). One low-dhurrin plant was selected in the $F_{2}$, one in the $F_{3}$, three in the $F_{4}, 11$ in the $F_{5}$, and 128 selected plants were random-mated in the $F_{6}$ generation in 1981 . Seed from $F_{6}$ genetic male-sterile plants was bulked and planted in 1982 for $S_{1}$ seed production. In 1983, $235 S_{1}$ 